\title{
New Insight: Chinese Tombstone Inscription Found in Barrang Lompo's Ancient Islamic Cemetery
}

\author{
$1^{\text {st }}$ Yadi Mulyadi \\ Archeology Postgraduate Student \\ Faculty of Humanities \\ Universitas Indonesia \\ Depok, Indonesia \\ yadi.mulyadi@ui.ac.id
}

\author{
$2^{\text {nd }}$ Irmawati Marwoto Djohan* \\ Archeology Department, Faculty of \\ Humanities \\ Universitas Indonesia \\ Depok, Indonesia \\ irmawati.marwoto@ui.ac.id
}

\author{
$3^{\text {rd }}$ Isman Pratama Nasution \\ Archeology Department, Faculty of \\ Humanities \\ Universitas Indonesia \\ Depok, Indonesia \\ isman.pratama@ui.ac.id
}

\begin{abstract}
Barrang Lompo is an island in the Spermonde archipelago in Makassar, South Sulawesi. As reflected by diverse ancient tombs dating to the $17^{\text {th }}$ century, this island has been inhabited by varied ethnic groups since the reign of the Gowa and Tallo kingdoms. Among the tombs discovered on the island, there are three that display Chinese inscriptions. This study aims to reveal the archeological and historical aspects of these tombs. The investigation utilizes archeological, historical, and philological analyses to achieve its objective. Archeologically, the shape and the orientation of one intact tomb reveals that the body it holds was buried as a follower of Islam in the $17^{\text {th }}$ century. A historical text that explains the process of Islamization of the Gowa-Tallo kingdoms during the same period supports the religious orientation of this tomb. Further, the inscriptions engraved in Chinese, Lontara, and Arabic scripts on tombstones found in at the graveyard site contain names and burial dates. An investigation of the inscriptions confirms that these tombstones reflect the multicultural life of that era and testify to the harmony that prevailed among ethnicities within the insular context of the island. This new finding provides significant insights regarding the ethnic diversity of Moslems during the time the Gowa-Tallo kingdoms flourished.
\end{abstract}

Keywords-Barrang Lompo, inscription, Islamic tomb, Makassar, Gowa-Tallo.

\section{Introduction}

Tombs are objects of research in Islamic Archeology. As examples of material culture, Islamic tombs evince a variety of shapes and attributes. These characteristics may be categorized as primary or secondary. Primary features such as headstone embody principal markers, while secondary elements such as the inscription are complementary. Both aspects, the headstone and the inscriptions, can be examined to determine the technology prevailing at a particular time, the spread of Islam at that juncture, and the influence of coexisting local traditions.

The region of South Sulawesi exemplifies how tombs can determine the spread of Islam. Several previous studies have reported that Islamization began in South Sulawesi in the $17^{\text {th }}$ century [1], [2], [3], [4], [5]. Other studies [6] suggest that the Islamization of South Sulawesi was closely related to the arrival and the integration of the Malay community to this region. Hadrawi's [6] study bolsters the well-established knowledge about the pivotal role of a Malay Ulama, who was the main actor in the process of the Islamization of South Sulawesi by converting the king of greater Gowa to Islam in 1605. Two years later, this ruler declared Islam the official religion of the joint Gowa-Tallo kingdoms. Traces of the spread of the religion and its growing influence in the region can be observed through the presence of Malay scholars in Bulukumba, Takalar, Makassar, and Luwu Timur [7].

Previously conducted studies have generally placed Malay scholars in the focal position of the Islamization of the South Sulawesi region. The veracity of this claim is questionable because in the $17^{\text {th }}$ century, Gowa-Tallo were twin maritime states in Eastern Indonesia. The significance of these kingdoms is reflected by the presence of a port that attracted traders from numerous parts of the world [8], [9]. Besides Malay scholars and European merchants, Chinese traders were also frequent visitors to the Port of Makassar in the $17^{\text {th }}$ century [10]. The Islamic tombs of people of Chinese ethnicity found in Barrang Lompo suggest that the Chinese traders were involved not merely in the regional trading activities, but were also engaged in the sociocultural life of the South Sulawesi area.

Despite this evidence, scholars rarely investigate the archeological or historical data pertaining to the contribution of people of Chinese origin to the early phases of the Islamization of South Sulawesi. The Chinese influence on the Islamic culture of South Sulawesi is worth examination to supplement investigations of the Chinese involvement in the flourishing trade in the South Sulawesi region when Gowa and Tallo reigned supreme.

The Islamic tombs found in Barrang Lompo island have studied by Haeruddin [11] and are also briefly mentioned by Muhaeminah [12], Muhaeminah and Makmur [13], and Rosmawati [4]. Haeruddin [11] described the existence of a Moslem-Chinese community in Barrang Lompo on the basis of the ornamentation and the Chinese inscriptions found on tombstones. The other mentioned authors only mentioned the tombs in passing with reference to Haeruddin's study [11]. All the above-mentioned authors have remarked on the tomb of Miss Lin Genio, who died in 1920 at the age of 82 .

Field observations conducted in 2018 on Barrang Lompo Island identified three gravestones that carried inscriptions in Chinese characters, and one that displayed Lontara inscriptions but displayed ethnic Chinese names. Two of the tombstones belong to a single intact tomb; the other two tombstones stand without their contextual tombs. Barrang Lompo is an island in the Spermonde Archipelago in Makassar, South Sulawesi. The ancient grave complex on Barrang Lompo Island is completely transformed from its 
original state as much of its material has been put to other uses such as local housing. As a result, many ancient tombs have been severely damaged or moved. Therefore, the present study investigates four gravestones. It may be categorized as a continuation of the study previously conducted by Haeruddin [11], Rosmawati [4], and Muhaeminah [12]. The object of the study comprises the said inscriptions on the tombstones which serve as important data for the appraisal of the role played by Chinese Muslims in the Islamization of the joint kingdoms of Gowa and Tallo between the seventeenth and the twentieth centuries.

\section{Method}

This paper results from an archeological investigation focusing on the detailed recording of artifacts discovered during field data collection. A literature study was conducted before the field visit to obtain preliminary data related to ancient tombs on Barrang Lompo Island and other relevant historical aspects. Subsequently, the researchers conducted the on-field data collection, observation, and documentation of the gravestones and inscriptions. Also, each headstone included as an object of this research endeavor was carefully measured.

Interviews were also conducted on Barrang Lompo Island with community leaders and other informants to obtain optimal information about the ancient and historical tomb complex. The next step involved the translation and philological analysis of the headstone inscriptions by linguistic specialists. The results of the analysis or the philological and interview-based data were further combined with the available historical and cultural landscape data on Barrang Lompo Island.

\section{Results and Discussion}

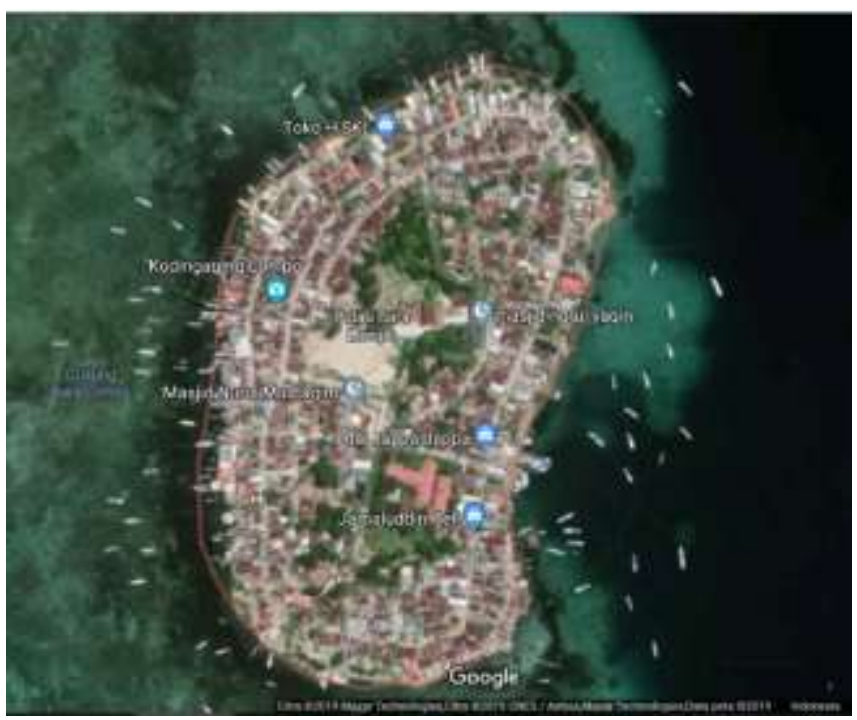

Fig.1. Aerial view of Barrang Lompo island

The island of Barrang Lompo is located about 9 miles to the West of the mainland of Makassar. It forms part of an archipelago of small islands in the Northwestern region of Makassar. Around 4000 people inhabit this 20.3-hectare island. The administrative area of the village of Barrang Lompo Island includes the Sangkarang archipelago district of Makassar city. This island now an alternative entertainment location for city residents, who enjoy its beach and sea views. The island is visited almost every day by tourists and is perhaps particularly popular because of its relative proximity to the town center of Makassar city. Most of the native population of this island is Moslem and most work as fishermen because of the largely coastal environment. Some local inhabitants also work as traders, silver craftsmen, and civil servants. The language of daily usage on the island is Makassar; however, other regional languages are also often used. The local community is quite warm and open. This attitude indicates their habit of interacting with external visitors. While on this island for the field visit, the researchers interviewed some residents and can thus personally testify to the cordiality of the local population.

Another interesting aspect of Barang Lompo residents is their varied regional and cultural backgrounds. The island is home not only to the Makassarese and the Buginese, but also to people of Mandar, Malay, Arabic, and Chinese origin. This diversity is also reflected in the divisions of the local settlements. The names of the settlement pockets within the island also reflect the regional origins of their residents. Thus, there are Makassar, Bugis, Mandar, Arab, and Malay villages. Nevertheless, the Barang Lompo community lives together as a unified Muslim entity: a diverse island community very close to the center of Makassar, but very far from the noise and bustle of a city that has presents its own social problematics.

In addition to its maritime potential, Barrang Lompo island is rich in its cultural heritage and offers immense cultural-historical and scientific value. The cultural heritage of the island takes the shape of Islamic tombs that date to the 17 th century and can thus be categorized as ancient and historical. This ancient tomb complex is located around the Nurul Yaqien mosque and the residential area that surrounds the place of worship. The grave complex exhibits traces of Chinese Muslim graves, which are the object of this study. At certain times of the year, many pilgrims visit this island from numerous regions such as Makassar, Gowa, and Maros. Tomb pilgrims hail from regions such as Polewali (Mandar), Jakarta, Sumatra, and Malaysia. A description of a Chinese Muslim tomb follows.

\section{Tomb A}

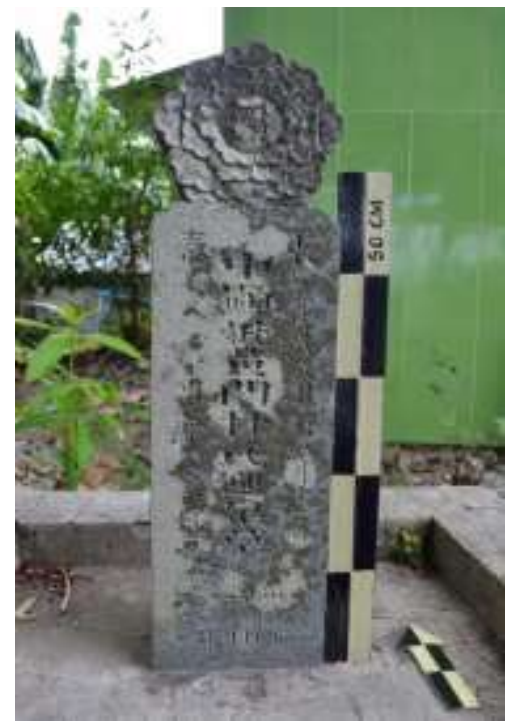

Fig.2. Photo of Headstone of Tomb A 
The data obtained from interviews reveal that Tomb A has been restored and only its headstone is original. The gravestone is $62 \mathrm{~cm}$ high and $8.5 \mathrm{~cm}$ thick in size. The inward side of the gravestone carries inscriptions engraved in the Chinese, Lontara, and Latin scripts. The Chinese characters convey information about the name of the buried person, a woman called Lin Yin Niang. When read in the Hokkien version, the name becomes Li Ge Nio. The name of the buried person is also inscribed in the Lontara inscription in which the local script is combined with Latin characters: Kuburu'na Miss Ling Geng Nio Umuru'na 82 Taung Ri tanggala 21-9-1920 namate (Ms. Ling Geng Nio died at the age of 82 on September 21, 1920).

\section{Tomb B}

Tomb B is rectangular. It is $235 \mathrm{~cm}$ long and $107 \mathrm{~cm}$ wide. There are two graves on the North and South of this tomb. The two headstones are flat and decorated with a medallion on the inward side. The medallion carries the engraved inscriptions. The headstone on the North of the tomb is inscribed in Arabic on the inward aspect and in Chinese characters on the outward aspect. The headstone to the South of the tomb sports only the medallionshaped decoration without any inscription.
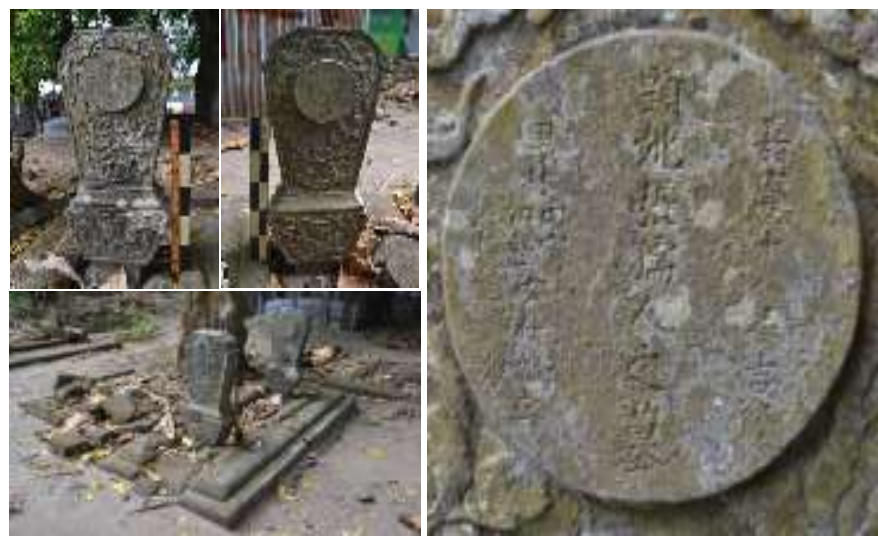

Fig.3. Photo of Tomb B and Its Inscription

The Arabic inscriptions on gravestones represent salvation prayers for buried spirits. The Chinese inscription reads the name of the buried person who is surnamed Cang and records the death as having occurred in the Chinese year called CiaChing or 1669.

\section{Tomb C}

This tomb is damaged, and only the tombstone remains. Interestingly, the inscription on this headstone is in Lontara and contains information about the name of a person buried by a Chinese lady.

\section{Conclusion}

The Islamic Chinese tombs in Barrang Lompo prove that people of Chinese origin were not merely bystanders during the period of the Islamization of South Sulawesi. The mix of languages and scripts on the historic tombstones suggests the presence of a complex cultural blending in South Sulawesi. Also, the variety of ethnic backgrounds of those buried in the ancient Barrang Lompo cemetery evidences the absence of social demarcations among the ethnic communities who inhabited the island. The tombs reflect the existence of a harmonious multicultural lifestyle of many ethnicities living in proximity in an insular context. This paper calls for a more elaborate study of the Chinese community on the island during the early years of the Islamization of South Sulawesi. A more intensive research endeavor is required to reveal the influences exerted by the Chinese community of the island and the roles it played in the Islamization of South Sulawesi.

\section{Acknowledgment}

The authors are indebted to Muhlis Hadrawi, Bahar Akkase Teng, and Yongris for their support in transcribing and translating the tombstone inscriptions. This study is also supported by grants from the Ministry of Research Technology and Higher Education of the Republic of Indonesia.

\section{References}

[1] Mattulada. (2011). Menyusuri Jejak Kehadiran Makassar dalam Sejarah (1510-1700) (Tracing Makassar's Presence in History (15101700)). (A. R. Hamid Ed.). Yogyakarta: Penerbit Ombak.

[2] Noordyyun, J. (1972). Islamisasi Makassar (Islamization of Makassar). (S. Gunawan, Trans.): Bharata.

[3] Patunru, A. D. (1969). Sedjarah Gowa (History of Gowa). Udjung Pandang: Jajasan Kebudajaan Sulawesi Selatan dan Tenggara.

[4] Rosmawati. (2013). Perkembangan Tamadun Islam di Sulawesi Selatan, Indonesia: dari Perspektif Arkeologi dan Sejarah (The Development of Tamadun Islam in South Sulawesi, Indonesia: from the Archaeological and Historical Perspective). (Doctoral Disertasi), University Sains Malaysia, Malaysia.

[5] Sewang, A. (2005). Islamisasi Kerajaan Gowa (Abad XVI sampai Abad XVII) (Islamization of the Kingdom of Gowa (XVI Century to XVII Century)). Jakarta: Yayasan Obor Indonesia.

[6] Hadrawi, M. (2015). Kedatangan dan Integrasi Orang Melayu di Sulawesi Selatan Sekitar Abad XV-XVII Berdasarkan Lontara (Arrival and Integration of Malays in South Sulawesi Around the XVXVII Ages Based on Lontara). (Doctoral Disertasi), UNIVERSITI KEBANGSAAN MALAYSIA, Bangi, Malaysia.

[7] Mulyadi, Y. (2017). Kemaritiman Kemelayuan dan Islamisasi di Sulawesi Selatan (Malaya Maritime Affairs and Islamization in South Sulawesi). Paper presented at the Seminar Antar Bangsa Ke 6 Arkeologi Sejarah dan Budaya di Alam Melayu (ASBAM), Johor Bahru, Malaysia.

[8] Paeni, M. (2007). Benteng Somba Opu sebagai Pusat Perdagangan Nusantara Abad ke-16 (Benteng Somba Opu as the Center of Nusantara Trade in the 16th Century). Paper presented at the Seminar 400 tahun Kota Makassar, Makassar.

[9] Poelinggomang, E. L. (2013). Kedudukan Makassar dalam Perkembangan Perdagangan Rempah-Rempah di Maluku (Makassar's Position in the Development of the Spice Trade in Maluku). Paper presented at the Brobudur Writer \& Cultural Festival 2013, Magelang.

[10] Reid, A. (1999). Asia Tenggara dalam Kurun Niaga 1450-1680 Jilid II - Jaringan Perdagangan Global Asia Tenggara (Southeast Asia in the Commercial Period 1450-1680 Volume II - Southeast Asia's Global Trade Network). (R. Z. Leirissa \& P. Soemitro, Trans.). Jakarta: Yayasan Pustaka Obor Indonesia.

[11] Haeruddin. (1991). Kompleks Makam Kuna Pulau Barrang Lompo Kotamadya Ujung Pandang (The Old Tomb Complex of Barrang Lompo Island, Ujung Pandang). (Thesis), Universitas Hasanuddin, Makassar.

[12] Muhaeminah. (2013). Tapak-Tapak Sejarah dan Arkeologi Islam di Sulawesi Selatan (Historical and Archeological Traces of Islam in South Sulawesi). In A. Duli (Ed.). Makassar: De La Macca.

[13] Muhaeminah, \& Makmur. (2015). Jejak Orang Melayu sebagai Penyebar Agama Islam di Kerajaan Gowa Tallo (The Footsteps of Malays as Spreaders of Islam in the Kingdom of Gowa Tallo). Jurnal "Al Qalam", Volume 21 Nomor 2 Desember 2015, 375 - 386. 